\title{
Efficient use of nitrogen in agriculture
}

\author{
T. Rütting $\cdot$ H. Aronsson $\cdot$ S. Delin
}

Received: 6 December 2017/ Accepted: 18 December 2017/Published online: 4 January 2018

(C) Springer Science+Business Media B.V., part of Springer Nature 2018

\begin{abstract}
In the lyrics of one of their most wellknown songs, the British rock band Dire Straits wrote "we have just one world, but we live in different ones". This can also be said about the Nitrogen $(\mathrm{N})$ world, where deficit of reactive $\mathrm{N}$ is limiting food production in many areas, still causing hunger today in the developing world, while excess of reactive $\mathrm{N}$ causes inefficient use and environmental problems in mainly the industrialized world.
\end{abstract}

Nitrogen is a major nutrient, essential for all living organisms. Although it is the main constituent of the air, $\mathrm{N}$ availability is the main limiting factor for productivity of terrestrial ecosystems, including agroecosystems. That $\mathrm{N}$ is one of the most important inputs in crop production is well documented by the existence of a billion $€$ fertilizer industry. The economic importance of $\mathrm{N}$ has been identified already more than 100 years ago (Löhnis 1913). Our modern

T. Rütting $(\bowtie)$

Department of Earth Sciences, University of Gothenburg, Gothenburg, Sweden

e-mail: tobias.rutting@gu.se

\section{H. Aronsson}

Department of Soil and Environment, Swedish University of Agricultural Sciences, Uppsala, Sweden

\section{S. Delin}

Department of Soil and Environment, Swedish University of Agricultural Sciences, Skara, Sweden society would not exist without the invention of technical creation of reactive $\mathrm{N}$, used to fertilize agricultural land in order to ensure food security for the growing global population (Erisman et al. 2008). On the one hand, the application of fertilizer in excessive amounts leads to environmental problems, such as eutrophication of waters, loss of biodiversity, global warming and stratospheric ozone depletion, often found in high-income areas. In fact, the costs of environmental $\mathrm{N}$ pollution are exceeding the added value due to $\mathrm{N}$ fertilization (Sutton et al. 2011b). On the other hand, limited access to mineral fertilizers leads to low yields and insufficient food supply, in many low-income areas (Sutton et al. 2011a). Worldwide, researchers are tackling the problems of how to improve soil fertility and $\mathrm{N}$ management for different type of climates, soils and crop conditions around the world. This includes increased yields, increased $\mathrm{N}$ use efficiency (NUE) and reduced losses to the environment in the short- and long-term.

The major challenge in intensive agricultural production systems is to combine intensive production with high NUE, since efficient use of $\mathrm{N}$ sources is the basis for combining future food security and minimized negative environmental impact. This includes strategies for $\mathrm{N}$ applications with organic and mineral fertilizers and also strategies for soil and crop management in order to utilize $\mathrm{N}$ mineralization processes in the soil or to avoid unwanted accumulation of mineralized $\mathrm{N}$ in the soil when there is a risk of losses. Nitrogen losses from agroecosystems occur via 
leaching of mainly nitrate $\left(\mathrm{NO}_{3}{ }^{-}\right)$and via emission of gaseous $\mathrm{N}$ forms, of which nitrous oxide $\left(\mathrm{N}_{2} \mathrm{O}\right)$ and ammonia $\left(\mathrm{NH}_{3}\right)$ are of main environmental concern (Sutton et al. 2011a). Much research work has been done on this topic, where key management practices are e.g., manure and mineral fertilizer applications techniques and precision agriculture (Sommer and Hutchings 2001; Robert 2002), different soil tillage strategies (Myrbeck et al. 2012), cover crops (Schipanski et al. 2014) and managing the soil microbial community (Richardson et al. 2009). Although much has been investigated, novel research is being conducted constantly in order to increase our knowledge on how to increase productivity and sustainability of agricultural soils. Results of such research need to be presented to and discussed both within the scientific community and with stakeholders and policy makers.

This special issue contains selected papers from the 19th Nitrogen Workshop which was held in Skara, Sweden, in June 2016 with the main theme "Efficient use of nitrogen from different sources-from theory to practice". Since 1982, researches from different parts of the world have regularly gathered for the Nitrogen workshop in different locations in Europe. The 2016 workshop was attended by 211 participants coming from 30 different countries worldwide and comprised of 4 keynote lectures, 22 oral presentations and 190 poster presentations. In addition two sessions with 7-8 parallel workshops where certain themes were discussed in groups and five parallel excursions completed the workshop. In the 19th Nitrogen Workshop, different system approaches, combining efficient use of $\mathrm{N}$ and low losses, where presented and discussed in four themes: (1) $\mathrm{N}$ dynamics in different farming systems, (2) Precision N Management, (3) Knowledge transfer and implementation, and (4) $\mathrm{N}$ processes at different scales. The papers in this special issue represent a wide range of topics as process studies, flux measurements, field- and farm-scale $\mathrm{N}$ budgets and international trade.

\section{Nitrogen dynamics in different farming systems}

Nitrogen dynamics is highly dependent on the farming system, and so are the challenges to optimize $\mathrm{N}$ efficiency within it. In animal production, feed and manure management are important factors for the farm $\mathrm{N}$ efficiency. Surveying more than nine hundred beef operations across Canada, Sheppard et al. (2018) showed that $\mathrm{N}$ budgets and NUE varied significantly among different types of beef operations. Forage based operations showed the largest $\mathrm{N}$ surplus and lower $\mathrm{NH}_{3}$ emissions than confinement housing, while finisher operations had the highest NUE, but also the highest $\mathrm{NH}_{3}$ emissions. For dairy farms in Sweden, Einarsson et al. (2018) compared three indicators for N emissions. Importantly, all three indicators had considerable uncertainty, due to biases in the estimation of biological $\mathrm{N}$ fixation. Therefore more research is needed to improve the $\mathrm{N}$ indicators, to avoid misleading information for decision-makers.

In cropping systems soil management is one factor that may influence the $\mathrm{N}$ dynamics. In Finland, Laine et al. (2018) investigated the in situ gross $\mathrm{N}$ mineralization rates in barley fields to evaluate the potential benefit of no till on the soil $\mathrm{N}$ supply. Overall, no tilled soil showed a higher gross $\mathrm{N}$ mineralization, indicating higher soil $\mathrm{N}$ supply, than mouldboard ploughed soil. This was accompanied by an increased soil $\mathrm{N}$ retention such as that ammonium immobilization was more enhanced than mineralization in no till at the expense of a decreased nitrification. Such a decreased gross nitrification relative to ammonium immobilization is an indicator for a decreased risk of $\mathrm{N}$ leaching (Stockdale et al. 2002), which led Laine et al. to conclude that no till of boreal arable soils decreases $\mathrm{N}$ leaching. In some farming systems catch crops are grown during the season without a main crop as a management option to reduce $\mathrm{N}_{2} \mathrm{O}$ and $\mathrm{NO}_{3}{ }^{-}$leaching (Schipanski et al. 2014). In a two year field trial, Komainda et al. (2018) investigated the effect of two catch crops, rye and ryegrass, in a maize cropping system on yield, $\mathrm{NO}_{3}{ }^{-}$leaching and $\mathrm{N}_{2} \mathrm{O}$ emissions. While the catch crops did neither affect the maize yield nor the $\mathrm{N}_{2} \mathrm{O}$ emission, rye significantly reduced $\mathrm{NO}_{3}{ }^{-}$leaching, despite the fact that $\mathrm{NO}_{3}{ }^{-}$leaching was below the EU critical load even in the fields without catch crop. Therefore, the use of a suitable catch crop might further reduce $\mathrm{NO}_{3}{ }^{-}$leaching even from crops which already optimized $\mathrm{N}$ fertilizer management.

\section{Precision nitrogen management}

In order to optimize fertilizer nitrogen inputs for high yields and minimized losses to the environment, 
accurate fertilizer requirements by the crop must be predicted. The fertilizer requirement is dependent on both crop requirement and $\mathrm{N}$ supply by the soil. The $\mathrm{N}$ supply from the soil varies between years and site, depending on soil and weather parameters. This was described by Ratjen and Kage (2018) who studied the impact of climatic and site-related factors on the effective $\mathrm{N}$ mineralization during the growing season in a large number of winter wheat experiments across Germany. The study revealed that both, climate and soil fertility were important factors for prediction of the effective $\mathrm{N}$ mineralization and have a significant effect on the soil $\mathrm{N}$ supply. Consequently, these factors carry valuable information for planning $\mathrm{N}$ fertilizer applications. The soil $\mathrm{N}$ supply does not only vary between farms and field, but also within the field. Córdova et al. (2018) studied the spatial correlation of $\mathrm{N}$ mineralization within an individual field, in order to guide future spatial sampling of $\mathrm{N}$ supply. Their data for a cereal cropping system in Chile showed that significant variation in net $\mathrm{N}$ mineralization existed, even at small spatial scale $(1.5 \mathrm{~m})$. Importantly, almost all of the variation was accounted for at a $40.5 \mathrm{~m}$ sampling distance. Furthermore, as no difference in variation was observed between autumn and spring, it was concluded that sampling can be done at any time during the crop growing season. Taking soil samples at high spatial resolution can be very expensive and time-consuming. As an alternative, crop sensors can be used to assess crop available N. These sensors, allowing quick and dense sampling and using crop parameters as an indicator of $\mathrm{N}$ supply, can be a good solution for assessing the site-specific $\mathrm{N}$ fertiliser requirements and its variation within individual fields. This was studied by Aranguren et al. (2018), who tested two commercially available proxy tools (crop sensors) for the $\mathrm{N}$ nutritional status of crops in winter wheat which had received manure at an earlier stage. The tools were shown to be as good indictors as soil mineral $\mathrm{N}$ or the $\mathrm{N}$ nutrition index, demonstrating their practical usefulness.

Precision $\mathrm{N}$ management with organic fertilizers involves an additional challenge as the organic fertilizer is usually not as well defined and predictable as the mineral fertilizers. Nitrogen Fertiliser Replacement Value (NFRV) is a measure for N supply from organic amendments to crops (Jensen 2013), representing the amount of mineral $\mathrm{N}$ fertiliser replaced by the organic amendment. Hijbeek et al.
(2018) used data from long term experiments in Europe and showed that NFRV were higher at high total $\mathrm{N}$ supply than at low total $\mathrm{N}$ supply. Therefore, requirements of mineral $\mathrm{N}$ fertiliser in fields with organic amendments might today be overestimated, causing an overuse of $\mathrm{N}$ fertilizers and leading to $\mathrm{N}$ losses to the environment.

\section{Knowledge transfer and implementation}

Many times there is a gap between scientific studies and what is actually implemented at farms. To bridge this gap the communication between scientists and practitioner must improve. Ravier et al. (2018) developed an $\mathrm{N}$ fertilization management by involving different users like farmers and authorities. New decisions rules for $\mathrm{N}$ fertilization were proposed based on the Azodyn model. This innovative fertilizer management has the potential to better synchronize the $\mathrm{N}$ fertilizer application with the crop $\mathrm{N}$ requirement to reduce $\mathrm{N}$ losses.

\section{Nitrogen processes at different scales}

The workshop theme about nitrogen processes at different scales, cover a wide range of topics, from the microbial processes in the field up to nitrogen budgets for large regions accounting for trade of inputs and products as well as microbial processes and losses with air and water. For developing mitigation options of $\mathrm{N}_{2} \mathrm{O}$ emissions from agricultural fields, not only reliable field data on the emissions are needed, but also a profound knowledge on the $\mathrm{N}_{2} \mathrm{O}$ production pathways. Usually, denitrification and nitrification are thought to be responsible for $\mathrm{N}_{2} \mathrm{O}$ production, but other microbial pathways of $\mathrm{N}_{2} \mathrm{O}$ production are known (Butterbach-Bahl et al. 2013). In grasslands, $\mathrm{N}_{2} \mathrm{O}$ production from codenitrification and the contributions of bacteria and fungi was investigated by Rex et al. (2018). Indeed, codenitrification contributed with $33 \%$ to the $\mathrm{N}_{2} \mathrm{O}$ production in urine-amended grassland soils, and was conducted by fungi. This study, hence, confirmed that other $\mathrm{N}_{2} \mathrm{O}$ production pathways need to be considered to fully understand the $\mathrm{N}_{2} \mathrm{O}$ emission from soils (Müller et al. 2014).

Significant losses of $\mathrm{N}$ occur from farms involving animal husbandry, manure management or 
fertilization with digestates from biogas plants. Three papers in this special issue are dealing with $\mathrm{NH}_{3}$ emissions. Digested organic material, which has been used for biogas production, is a valuable form of organic fertilizer (Abubaker et al. 2012; Nkoa 2014). However, the application of biogas residues as fertilizer might be associated with enhanced $\mathrm{NH}_{3}$ emissions (Tiwary et al. 2015). Nicholson et al. (2018) tested different digestates and application techniques in a temperate grassland to identify fertilization approaches that minimize $\mathrm{NH}_{3}$ emissions. The study demonstrated that food-based digestates had higher $\mathrm{NH}_{3}$ emission compared to digestates from cattle slurry. Regardless of digestate form, precision application and particularly shallow injection reduced the $\mathrm{NH}_{3}$ emissions up to $50 \%$, which hence is a suitable method for mitigation of $\mathrm{NH}_{3}$ emissions. Another management option that has been suggested to reduce $\mathrm{NH}_{3}$ emission from manure is to decrease the crude protein in the animal diet (Chadwick et al. 2011). By conducting a meta-analysis, Sajeev et al. (2018) could show that reducing the crude protein in cattle and pig diets indeed reduced $\mathrm{NH}_{3}$ emissions by on average $17 \%$ (cattle) and $11 \%$ (pigs). Emission factors are used to compile large scale inventories of emissions if not sufficient measurements are available. Pacholski et al. (2018) used two modelling approaches to estimate $\mathrm{NH}_{3}$ emission from three cropping systems in Germany, where $\mathrm{NH}_{3}$ emissions deviating from standard emission factors were used. Scenario modelling based on weather and soil data, using a statistical model, was able to predict $\mathrm{NH}_{3}$ emissions satisfactorily and hence can be a suitable tool to derive robust $\mathrm{NH}_{3}$ emissions factors for fertilized cropping systems.

Finally, Wang et al. (2018) analysed international trade of agricultural products and the national nutrient balances of the food systems, focussing on soybean and maize for animal feed. Importing countries showed a wide span of $\mathrm{N}$ surplus and the two cops investigated accounted together for up-to $40 \%$ of the national $\mathrm{N}$ balance.

\section{Concluding remarks}

To close, we would like to thank all the participants of the 19th Nitrogen Workshop and the authors of the papers in this special issue. It is the contributions of those scientists who advance our knowledge on the $\mathrm{N}$ cycling, management and losses in and from agroecosystems. With those contributions, either as presentation and discussion during workshops and meetings or, ultimately, as authors in peer-reviewed articles, we advance our knowledge that will lead to a more wise and efficient use of $\mathrm{N}$ and a cleaner environment. While the contributions collected in this special issue certainly contributed new knowledge, still much is to be explored. Therefore research goes on and the series of Nitrogen Workshops will continue to contribute to the much needed knowledge on $\mathrm{N}$ cycling in agroecosystems.

Acknowledgements We would like to thank all reviewers for the valuable contribution to this Special issue. The 19th nitrogen workshop was financial supported by Financial support was given by The Swedish Research Council Formas, the Västra Götaland Region and Yara. Tobias Rütting is supported by the Strategic Research Area BECC (Biodiversity and Ecosystem Services in a Changing Climate; www.becc.lu.se).

\section{References}

Abubaker J, Risberg K, Pell M (2012) Biogas residues as fertilisers-effects on wheat growth and soil microbial activities. Appl Energy 99:126-134

Aranguren M, Castellon A, Aizpurua A (2018) Topdressing nitrogen recommendation in wheat after applying organic manures: the use of field diagnostic tools. Nutr Cycl Agroecosyst. https://doi.org/10.1007/s10705-017-9865-7

Butterbach-Bahl K, Baggs EM, Dannenmann M, Kiese R, Zechmeister-Boltenstern S (2013) Nitrous oxide emissions from soils: how well do we understand the processes and their controls? Philos Trans R Soc Lond B Biol Sci 368:20130122

Chadwick D, Sommer S, Thorman R, Fangueiro D, Cardenas L, Amon B, Misselbrook T (2011) Manure management: implications for greenhouse gas emissions. Anim Feed Sci Technol 166:514-531

Córdova C, Barrera JA, Magna C (2018) Spatial variation of nitrogen mineralization as a guide for variable application of nitrogen fertilizer to cereal crops. Nutr Cycl Agroecosyst. https://doi.org/10.1007/s10705-017-9886-2

Einarsson R, Cederberg C, Kallus J (2018) Nitrogen flows on organic and conventional dairy farms: a comparison of three indicators. Nutr Cycl Agroecosyst. https://doi.org/10. 1007/s10705-017-9861-y

Erisman JW, Sutton MA, Galloway JN, Klimont Z, Winiwarter W (2008) How a century of ammonia synthesis changed the world. Nat Geosci 1:636-639

Hijbeek R, ten Berge H, Whitmore A, Barkusky D, Schröder J, van Ittersum M (2018) Nitrogen fertiliser replacement values for organic amendments appear to increase with $\mathrm{N}$ application rates. Nutr Cycl Agroecosyst. https://doi.org/ 10.1007/s10705-017-9875-5 
Jensen LS (2013) Animal manure fertiliser value, crop utilisation and soil quality impacts. In: Sommer SG, Christensen ML, Schmidt T, Jensen LS (eds) Animal manure recycling: treatment and management. Wiley, Hoboken, pp 295-328

Komainda M, Taube F, Kluß C, Herrmann A (2018) Effects of catch crops on silage maize (Zea mays L.): yield, nitrogen uptake efficiency and losses. Nutr Cycl Agroecosyst. https://doi.org/10.1007/s10705-017-9839-9

Laine M, Rütting T, Alakukku L, Palojärvi A, Strömmer R (2018) Process rates of nitrogen cycle in uppermost topsoil after harvesting in no-tilled and ploughed agricultural clay soil. Nutr Cycl Agroecosyst. https://doi.org/10.1007/ s10705-017-9825-2

Löhnis F (1913) Vorlesungen über landwirtschaftliche Bakteriologie. Verlag von Gebrüder Bornträger, Berlin

Müller C, Laughlin RJ, Spott O, Rütting T (2014) Quantification of $\mathrm{N}_{2} \mathrm{O}$ emission pathways via a ${ }^{15} \mathrm{~N}$ tracing model. Soil Biol Biochem 72:44-54

Myrbeck Å, Stenberg M, Arvidsson J, Rydberg T (2012) Effects of autumn tillage of clay soil on mineral $\mathrm{N}$ content, spring cereal yield and soil structure over time. Eur J Agron 37:96-104

Nicholson FA, Bhogal A, Rollett A, Taylor M, Williams J (2018) Precision application techniques reduce ammonia emissions following food-based digestate applications to grassland. Nutr Cycl Agroecosyst. https://doi.org/10.1007/ s10705-017-9884-4

Nkoa R (2014) Agricultural benefits and environmental risks of soil fertilization with anaerobic digestates: a review. Agron Sustain Dev 34:473-492

Osterholz WR, Rinol O, Shaviv A, Linker R, Liebman M, Sanford G, Strock J, Castellano MJ (2017) Predicting gross nitrogen mineralization and potentially mineralizable nitrogen using soil organic matter properties. Soil Sci Soc Am J 81:1115-1126

Pacholski AS, Doehler J, Schmidhalter U, Kreuter T (2018) Scenario modeling of ammonia emissions from surface applied urea under temperate conditions-application effects and model comparison. Nutr Cycl Agroecosyst. https://doi.org/10.1007/s10705-017-9883-5

Ratjen AM, Kage H (2018) Predicting the site specific soil N supply under winter wheat in Germany. Nutr Cycl Agroecosyst. https://doi.org/10.1007/s10705-017-9850-1

Ravier C, Jeuffroy M-H, Gate P, Cohan J-P, Meynard J-M (2018) Combining user involvement with innovative design to develop a radical new method for managing $\mathrm{N}$ fertilization. Nutr Cycl Agroecosyst. https://doi.org/10. 1007/s10705-017-9891-5
Rex D, Clough TJ, Richards KG, de Klein C, Morales SE, Samad S, Grant J, Lanigan GJ (2018) Fungal and bacterial contributions to codenitrification emissions of $\mathrm{N}_{2} \mathrm{O}$ and $\mathrm{N}_{2}$ following urea deposition to soil. Nutr Cycl Agroecosyst. https://doi.org/10.1007/s10705-017-9901-7

Richardson DJ, Felgate H, Watmough N, Thomson AM, Baggs EM (2009) Mitigating release of the potent greenhouse gas $\mathrm{N}_{2} \mathrm{O}$ from the nitrogen cycle-could enzymic regulation hold the key? Trends Biotechnol 27:388-397

Robert PC (2002) Precision agriculture: a challenge for crop nutrition management. Plant Soil 247:143-149

Sajeev EPM, Ammon C, Zollitsch W, Winiwarter W (2018) Evaluating the potential of dietary crude protein manipulation in reducing ammonia emissions from cattle and pig manure: a meta-analysis. Nutr Cycl Agroecosyst. https:// doi.org/10.1007/s10705-017-9893-3

Schipanski ME, Barbercheck M, Douglas MR, Finney DM, Haider K, Kaye JP, Kemanian AR, Mortensen DA, Ryan MR, Tooker J, White C (2014) A framework for evaluating ecosystem services provided by cover crops in agroecosystems. Agric Syst 125:2-22

Sheppard S, Bittman S, Ominski K (2018) Nitrogen budget estimated for 908 cow-calf, backgrounding and finishing beef operations across Canada. Nutr Cycl Agroecosyst. https://doi.org/10.1007/s10705-017-9863-9

Sommer SG, Hutchings NJ (2001) Ammonia emissions from field applied manure and its reduction—invited paper. Eur J Agron 15:1-15

Stockdale EA, Hatch DJ, Murphy DV, Ledgard SF, Watson CJ (2002) Verifying the nitrification to immobilisation ratio (N/I) as a key determinant of potential nitrate loss in grassland and arable soils. Agronomie 22:831-838

Sutton MA, Howard CM, Erisman JW, Billen G, Bleeker A, Grennfelt P, van Grinsven H, Grizzetti B (2011a) The European Nitrogen Assessment. Cambridge University Press, Cambridge

Sutton MA, Oenema O, Erisman JW, Leip A, van Grinsven H, Winiwarter W (2011b) Too much of a good thing. Nature 472:159-161

Tiwary A, Williams ID, Pant DC, Kishore VVN (2015) Assessment and mitigation of the environmental burdens to air from land applied food-based digestate. Environ Pollut 203:262-270

Wang J, Liu Q, Hou Y, Qin W, Lesschen JP, Zhang F, Oenema $\mathrm{O}$ (2018) International trade of animal feed: its relationships with livestock density and $\mathrm{N}$ and $\mathrm{P}$ balances at country level. Nutr Cycl Agroecosyst. https://doi.org/10. 1007/s10705-017-9885-3 